Dolev-Cohen, M., \& Ricon, T. (2020). Demystifying sexting: Adolescent sexting and its associations with parenting styles and sense of parental social control in Israel. Cyberpsychology: Journal of Psychosocial Research on Cyberspace, 14(1), Article 6.

\title{
Demystifying Sexting: Adolescent Sexting and its Associations With Parenting Styles and Sense of Parental Social Control in Israel
}

\author{
Michal Dolev-Cohen \& Tsameret Ricon
}

Oranim Academic College of Education, Tivon, Israel

\begin{abstract}
The present study examined sexting habits (sending text messages, as well as nude or semi-nude photos, and/or requesting the same from others) among adolescents, as reported by 458 students (101 boys, 357 girls), with the aim of investigating whether and how sexting correlates with parenting styles and manifestations of parental social control. An online link was published on social media, asking participants who meet the research criteria to complete several questionnaires. About $30 \%$ of the participants reported sending sexual messages, and almost 32\% reported that others, mainly strangers, asked them to send nude or semi-nude photos. Furthermore, sexting was more common among high-school students than among middle-school students, and asking another person to send nude or semi-nude photos was more common among boys than among girls. Lower parental social control was related to increased likelihood of sexting, and higher perception of permissive parenting style was associated with asking someone else to send nude or semi-nude photos. These findings shed light on sexting among adolescents in Israel. Moreover, the findings show that adolescents do not report sexting either to parents or to other significant adults in their lives, such as teachers or other educational staff at school. The article concludes with implications for educators and educational counselors in view of these findings.
\end{abstract}

Keywords: Sexting; adolescence; Internet; parenting style; social control

\section{Introduction}

Technology is an integral part of adolescents' lives today (Lenhart et al., 2010). In such an era, it seems natural for adolescents to express themselves online and to exploit the abundance of Internet apps for their needs. The privacy afforded by the smartphone, the disinhibition (Suler, 2004), the increasing importance of the peer group, and the changes occurring in adolescence (Steinberg, 2008) allow adolescents to explore their sexuality in cyberspace through sexting activities (Gordon-Messer et al., 2013). In this context, parents need to address sexting when educating their children about sex, as sexting may well affect both participants (the sender, if the image is distributed, and the recipient, who may find the sexual content offensive). The parenting style and social control exercised by the parents may determine their offspring's overall behavior, including their risk behavior and, given that parents are major socialization agents, they can play a significant role in educating their children about the possible negative consequences of sexting (Vanwesenbeeck et al., 2018). However, to date, the association of these parent-related variables with adolescents' sexting behaviors has not been studied.

\section{Adolescents and Smartphone Use}

Most teenagers carry smartphones, giving them access to social online space anytime and anywhere (Duggan et al., 2015). Various studies around the world have pointed out the high rates of smartphone use among teenagers. For example, in a survey conducted in the United States, the Pew Research Center found that 88\% of adolescents between the ages of 13 and 17 owned a cellphone (Duggan et al., 2015). Another US study that examined over 1,000 adolescents of ages 13 to 17 found that $73 \%$ of them owned a smartphone and $15 \%$ owned a cellphone without advanced functionality, while only $12 \%$ did not own a cellphone (Anderson, 2015). It is important to note that a smartphone is not merely a telephone. Indeed, it is a computer that includes a user-friendly camera, so that even very young children can send photos to their friends and family members (Arcabascio, 2010). In addition, Duggan et al. (2015) found that youngsters with cellphone Internet access spent more time online than those without this readily 
available medium. Teenagers who owned a smartphone reported texting as their favorite means of communication, preferred over social networks or phone calls (Anderson, 2015). Adolescents make extensive use of smartphones for social needs typical of their age, both to maintain their social network and to create new friendships (Valkenburg \& Peter, 2009), including for romantic purposes (Daneback et al., 2009). The online disinhibition and the lack of eye contact lead users to perceive a sense of privacy, which invites not only emotional disclosure but also bodily exposure (Agustina, 2015; Lapidot-Lefler \& Barak, 2012; Suler, 2004). Sexting was found to be typical of teenage couples in romantic relationships, especially couples hoping to develop a romantic relationship, or couples who shared photos with others outside of the romantic relationship (Lenhart, 2009).

\section{Sexting}

The narrow definition of sexting is the sending of self-created nude or semi-nude photographs to someone else. More broadly, sexting refers to sending and receiving sexually explicit messages and images (Cooper et al., 2016; Klettke et al., 2019). In this article, we refer to sexting as the sending of sexual text messages and pictures, as well as engaging (as requestor or responder) in the exchange of nude or semi-nude photographs. Sexting is portrayed in the research literature as an expression of sexuality, and researchers agree that sexting is used by adolescents to explore their sexuality (Dir et al., 2013; Döring, 2014; Henderson \& Morgan, 2011). In relation to specific sexting behavior, it was found that the sending and receiving of text messages with sexual contents were significantly associated with each other (Rice et al., 2014); however, sexting with images was associated with higher rates of sexual activity among at-risk adolescents, more than sending text with explicit sexual contents, also referred to as sexts (Houck et al., 2014). A recent meta-analysis study found that the receiving sexts was more prevalent than the sending of sext messages (Madigan et al., 2018)

Adolescents reported sending revealing images either at the request of their girlfriend/boyfriend (Englander, 2012) or to maintain intimacy while they were apart (Drouin et al., 2013). Other motives postulated by researchers include developing one's sexual identity (Van Ouytsel, Van Gool et al., 2017) or merely alleviating boredom (Kopecký, 2012). Delevi and Weisskirch (2013) found that extraversion was associated with engaging in text-based sexting, while neuroticism predicted sexting with images. A Spanish study of the factors related to sexting found that cybergossip and the need for popularity were the most prevalent driving factors among girls, whereas demonstrating normalization in adolescent culture and the willingness to sext were the most prevalent factors among boys (Casas et al., 2019). For adolescents, sexting often appears to be a means of flirtation and harmless entertainment when feeling good about themselves and their sexuality (Dir et al., 2013; Lenhart, 2009). In cases involving romantic partners, sexting was not found to be a marker of risk behaviors (Van Ouytsel et al., 2018); however, sexting among adolescents, in general, has been associated with sexual offenses, such as the trading or possession of pornographic images (Arcabascio, 2010). A recent study found that non-partnered adolescents who engaged in sexting outside a romantic relationship were more likely to report substance use (compared to their non-sexting peers) (Van Ouytsel et al., 2018).

Instant messaging apps that can be used to send images and short clips make sexting easy. Indeed, sexting among celebrities, politicians, and other role models is often exposed in the media (Davidson, 2015); hence, although unfortunate, it is not surprising that adolescents also engage in sexting, despite its possible risks (Madigan et al., 2018; Strassberg et al., 2017). A study of students in grades 6-12 revealed that 17\% used sexting; among the 12-year-olds, the rate of use was 3\%, and among the 18-year-olds it was 32\% (Dake et al., 2012). Another study examined 1,839 students enrolled in grades 7-12 in Los Angeles, California, and found that $15 \%$ of smartphone users practiced sexting (Rice et al., 2012). A study of 3,503 high-school students in Sweden found that $20.9 \%$ of adolescents posted self-created nude images online. A meta-analysis of articles published between 2011 and 2015 on the subject of sexting found that the prevalence rates of sexting ranged from $2.5 \%$ to $24 \%$, with an estimated mean of $10.2 \%$ (Kosenko et al., 2017). A more recent study revealed that one in seven adolescents engage in sexting as senders while one in four are involved as recipients; furthermore, over the years, sexting has become more common among adolescents (Madigan et al., 2018). As noted, in-and-of-itself, sexting can be considered an expression of one's sexuality, yet the fact that it occurs online exposes users to risks, such as privacy violation due to distribution, harassment, cyberbullying, blackmail, revenge after breakup, etc. (Madigan et al., 2018; Van Ouytsel, Van Gool et al., 2017). Nevertheless, it seems that young people tend to perceive sexting as a private matter (Hasinoff $\&$ Shepherd, 2014).

\section{Sexting and Gender}

When it comes to sexting, the research literature is inconclusive regarding the effects of the gender variable. Some studies report finding no gender differences (Hudson \& Fetro, 2015; Lenhart, 2009; Madigan et al., 2018), whereas others report that girls engage in sexting more than do boys (Mitchell et al., 2012; Reyns et al., 2014), and still others suggest that boys are more likely to sext than girls (Delevi \& Weisskirch, 2013; Garcia et al., 2016; Klettke et al., 2018). A systematic search of databases (Klettke et al., 2014) showed that although findings relating to gender are somewhat mixed, there is some evidence that females may be more likely to send sexts than males and, accordingly, males may be more likely to receive them. These gender differences may be explained, in part, by the finding that being pressured by others was a causal factor in female sexting behavior (Englan der, 2012; Henderson \& Morgan, 2011). 
In an attempt to resolve this issue, a study in Sweden examined different types of sexting. The study found that more boys than girls tended to send self-produced semi-nude images and clips and to engage in sexual activity in front of a web camera, whereas girls tended to expose themselves via web cameras and smartphones (Jonsson et al., 2014). Another study suggested that gender differences may be related to cultural factors. In traditional countries, boys typically engage in sexting behaviors more than do girls, whereas, in non-traditional countries, gender differences were scarce (Baumgartner et al., 2014). Given that Israeli society exhibits a high degree of traditionalism (Lavee \& Katz, 2003), it is characterized by unequal gender roles (Boehnke, 2011). Accordingly, girls tend to be more protected by their parent and hence are subjected to more rules, intended to restrict their sexual activity (De Gaston et al., 1996) and promote sexual passiveness (Kiefer \& Sanchez, 2007). Therefore, we hypothesized that Israeli boys would engage in sexting more often than would girls.

\section{Parenting and Parenting Styles}

Parents play a central role in adolescents' socialization. According to a qualitative study, it appears that boys often ask girls to engage in sexting as a demonstration of their mutual love and that the girls feel emotionally pressured to acquiesce (Van Ouytsel, Torres et al., 2017; Van Ouytsel, Van Gool et al., 2017). However, it was also found that when boys' parents set down rules about sending and receiving sexual messages, the boys were less likely to engage in sexting (West et al., 2014). Therefore, it is important to examine whether sexting is linked to the absence of parental social control or to permissive education and whether parenting styles and practices have an impact on the extent and manner of sexting among adolescents.

The issue of parenting styles and parental mediation has become increasingly crucial as sexting behavior is becoming a more common form of intimate communication among adolescents. Parents need to address the dangers inherent in this type of communication in the context of their children's sexual education (Vanwesenbeeck et al., 2018).

Parenting itself is perceived and defined in many ways. Darling and Steinberg (1993) proposed an important distinction between parenting styles and parenting practices. "Parenting style" is a term coined by Baumrind (1977) and expresses the variable balance between two main dimensions: parental responsiveness and parental demandingness. Responsiveness is directed toward the connection between children's and parents' behaviors and emphasizes the intention in the parental response. Responsiveness refers to the extent to which parents intentionally encourage individuality and self-regulation and emphasize their children's selfassertion, all the while serving as a source of support and responding to their needs. Parents with high parental responsiveness are open to discussing their children's needs and requests with them and are described as warm and supportive. Parental demandingness refers to the range of demands parents place on their children, by setting behavioral standards and controls to facilitate their inclusion in the family structure (Maccoby \& Martin, 1983). Parents with a high degree of demandingness set high standards, to which they expect their children to conform. Baumrind identified three parental disciplinary styles deriving from these dimensions (1991):

a. Permissive style: This style is characterized by a low level of demandingness and a reluctance to impose limits, along with a high level of responsiveness. These parents tend to demand less from their children and permit them to self-regulate their activities, while avoiding setting parental restrictions. They convey warmth and acceptance toward their children with minimal use of punishment.

b. Authoritarian style: These parents impose high demands on their children while demonstrating low levels of parental responsiveness. They convey a low level of warmth and acceptance and tend to be opinionated and strict with their children. They impose clear restrictions and prefer to deal with disobedience through punishment. Parents characterized by an authoritarian parenting style believe in the power of authority and discipline and demonstrate decisiveness and confidence when interacting with their children (Rea \& Rossman, 2005; Reitman et al., 2002). Hierarchy and obedience without explanation are prominent in their parent-child relationships. These parents believe that their children are highly capable of exercising self-control and accepting responsibility. Such a perception does not always reflect reality (Scott-Little \& Holloway, 1994); consequently, these parents do not hesitate to take active steps (e.g., confiscating telephones, checking phone messages) for purposes of control and education.

c. Authoritative style: This style is characterized by parents who strike a balance between parental demandingness and parental responsiveness. These parents give their children clear instructions, while setting demands they can easily understand and supervising their behavior. Discipline is mediated by warmth, explanations, flexibility, and willingness for verbal negotiation to adapt the demands to the child's needs and level of understanding (Baumrind, 1991). Authoritative parenting helps children develop into independent and responsible human beings, encouraged by their parents' demanding-yet warm and nonintrusive--behavior.

\section{Parenting Styles and Their Influence on Children's Well-Being}

Children of authoritative parents exhibit significantly better emotional, social and learning competence than do children who grew up with parents who adopted other parenting styles (Omer, 1999). They demonstrate high interpersonal empathic capabilities and other varied social skills. They tend to develop fewer behavioral disorders and internal disorders such as depression and substance 
addiction. The findings show that these children use effective coping strategies when encountering difficulty and have high scholastic achievements.

Authoritative parenting style is a resilience factor for children from normative populations and even for children at risk (Omer, 1999). To a large extent, authoritative parenting is based on acceptance, alongside a high degree of strict supervision. In the case of adolescents, for example, parents characterized by an authoritative style impose clear behavioral standards and are assertive but not intrusive or restrictive. They attempt to guide the adolescent, but without being overprotective. Discipline is seen as a supportive rather than a punishing framework. This parenting style encourages autonomy and individuality (Omer, 1999; Querido et al., 2002; Reitman et al., 2002).

Permissive parenting is based on giving children "almost unrestricted freedom," based on the view that good parents need to be considerate of their children and their wishes (Robinson et al., 1995; Solberg, 2007). For example, permissive parents are very responsive to their children's needs, enable their self-regulation, avoid conflicts, and impose few demands. This parenting style often stems from the parents' difficulty in performing parenting tasks, such as coping with conflict (Omer, 1999).

Studies that examined the relationship between parenting styles and children's behaviors and attitudes showed that the authoritative style was linked to children's normative functioning to a much greater extent than the other parenting styles (McKinney et al., 2008; Rossman \& Rea, 2005). Indeed, a study that examined the relationship between parenting styles and adolescents' emotional state found that adolescents who reported intrusiveness and strict supervision exhibited many more symptoms of distress, depression, and behavioral problems than did adolescents who experienced an authoritative parenting style, characterized by a warm parent-child relationship (Jacobson \& Crockett, 2000).

Given that parenting styles differ in terms of the extent of parental demands and in parents' degree of responsiveness to their children (Baumrind, 1991), the variable of parenting style has been associated with the mediating role that parents play in their children's online behaviors (Vanwesenbeeck et al., 2018). As such, the parenting style is likely to affect adolescents' sexting activities as well. The authoritative style is associated with better consequences than either the authoritarian or the permissive styles, which are linked to higher risk behavior, such as sexting (de Graaf et al., 2011). Therefore, we hypothesized that there is an association between adolescents' involvement in sexting and their perceptions of their parents' parenting style, so that adolescents who perceived their parents' parenting style as authoritative would engage less in sexting activities than would their counterparts, who perceive their parents' parenting style to be either authoritarian or permissive.

\section{Control Theory and Parental Social Control}

The aim of social control is to maintain certain norms and prevent harm (Lewis \& Butterfield, 2005). Theories of social control assume that violating social norms can be enjoyable and profitable, leading many people to violate them (Liska \& Reed, 1985). The aim of social control theory is to understand why most people nevertheless are not criminals (Matsueda, 1982). According to control theory, the existence of social bonds may be what prevents individuals from engaging in socially deviant behaviors (Fagan \& Pabon, 1990; Hirschi, 1969). Hirschi (1969) identified four components of social bonds: attachment, commitment, involvement, and belief, arguing that strong bonds dissuade individuals from acting on their natural deviant dispositions and also discourage them from associating with delinquent companions (Hirschi, 1969). As it has been established that socialization takes place within the context of close relationships (Pugliese \& Okun, 2014), the research literature identifies parenting as one of the most important factors influencing adolescents' social control quality (Gottfredson \& Hirschi, 1990; Unnever et al., 2003). Therefore, adolescents' parental attachment (bonds with parents) and involvement (time spent doing shared activities), are considered components of parental social control. Parental social control refers to parents' efforts to influence and regulate their children's behavior (Pugliese \& Okun, 2014). During adolescence, parental social control appears to be associated with parents' rule regulation and adolescents' rule compliance (Lewis et al., 2004).

In the current study, we sought to discover whether sexting among adolescents is related to parental social control. Hence, we hypothesized that there would be a negative correlation between adolescents who perceived their parents as exercising a high degree of social control (measured in terms of attachment and involvement) the adolescents' involvement in sexting activities. Identifying such a link between these two variables could lead to the design of a more targeted intervention, thus leading to more effective prevention.

\section{The Current Study}

Based on the above research findings, the aim of the current study was to investigate whether there is a correlation between adolescents' involvement in sexting, their perceptions of their parents' parenting style, and their perceptions of parental social control. We hypothesized that boys would engage in sexting more than girls, that parenting styles would be related to sexting, and that adolescents' perceptions of strong parental social control would be negatively correlated to sexting, such that the higher the adolescents' sense of parental social control, the less they would engage in sexting. 


\section{Methods}

\section{Participants}

The present study included 458 adolescents living in different regions across Israel: 357 girls (77.9\%) and 101 boys (22.1\%). They ranged in age from 12 to 18 years $(M=15.57$ years; $S D=1.53)$. They included $175(38.2 \%)$ middle school students (age range $12-$ $15, M=14.02, S D=0.85$ ) and $283(61.8 \%)$ high school students (age range $15-18, M=16.52, S D=0.92$ ). All participants attended secular schools and reported owning a smartphone.

Participation in the study was on a voluntary basis. They were recruited via an online ad placed on social networks (Facebook and Instagram) during 2016. The ad invited them to complete an anonymous online questionnaire for an academic research project. Those who chose to click on the link were directed to a landing page, where they found information about the study and were asked to obtain their parents' consent. Before they were give access to the questionnaire, they had to indicate that their parents did not object to their participation. Participants were not identified and results are presented in the form of group data rather than individual data.

\section{Instruments}

Demographics and Sexting Questionnaire. The questionnaire was composed of general questions regarding the participant's age, grade in school, gender, and use of chat apps. Participants were asked four yes-no questions about their sexting behavior: (1) sending sexual messages, (2) sending messages containing either nude or semi-nude images, (3) asking someone else to send nude or semi-nude images, and (4) asking someone else to receive nude or semi-nude images from the participant. Additional questions were related to reporting and telling others about sexting messages that were sent and received (who did you tell about it? no one, friend, sibling, counselor, teacher, parent, another adult). The questionnaire was compiled for the purpose of this study and therefore, was written in Hebrew.

Parental Authority Questionnaire (Buri, 1991). This questionnaire includes 30 items, through which adolescents indicate how they perceive the parenting style by which they are raised and educated. Three types of parenting styles are examined: permissive, authoritarian, and authoritative. Each type is represented by 10 items on the questionnaire. Participants responded on a 5 -point Likert scale, ranging from 1 = strongly disagree to 5 = strongly agree. Parenting style was measured for both parents together. The questionnaire has been used in numerous studies in Israel (for example: Boniel-Nissim et al., 2020; Macmull \& Ashkenazi, 2019; Yaffe, 2018); hence, a Hebrew version was available. In the present study, internal consistency was $\alpha=.72$ for permissive parenting style, $\alpha=.86$ for authoritarian style, and $\alpha=.87$ for authoritative style. A principal component factor analysis with Varimax rotation supported the three factors: for the authoritative parenting style, Eigenvalue $=7.40$, representing $24.68 \%$ of the explained variance; for the authoritarian style, Eigenvalue $=3.33$, representing $11.09 \%$ of the explained variance; and for permissive style, Eigenvalue $=2.44$, representing $8.13 \%$ of the explained variance $(\mathrm{KMO}=.91, p<.001)$.

Social Control Theory Questionnaire (Hirschi, 1969). This questionnaire was used to examine participants' perceptions of parental social control. An existing Hebrew version of this questionnaire had been applied in several previous studies. For the purposes of the current study, a briefer version of the translated version (Wilchek-Aviad, 2005) was used, namely, only the bonds of attachment and involvement were examined, as they are directly related to and considered evidence of parental social control. Thus, a total of 27 items were used. The following are examples of the items used: "I spend a significant amount of time with my parents" and "I consider my parents' opinions." Participants rated the items on a 5-point Likert scale ranging from "strongly disagree" to "strongly agree" and "don't know." Internal consistency was $\alpha=.92$. According to the results of the principal component factor analysis, the questionnaire may be regarded as being composed of a single factor. The attachment factor accounted for $34.26 \%$ of the explained variance, with an Eigenvalue of 8.91, whereas the involvement factor accounted for only $7.20 \%$ of the explained variance $(\mathrm{KMO}=.90, p<.001)$.

\section{Data Analysis}

Data were analyzed using SPSS version 25. Descriptive statistics were used to measure participants' sexting behaviors, and $\chi^{2}$ was used to analyze group relationships with respect to gender and age groups. Sexting variables were formulated as dichotomous or categorical variables. Principal component factor analysis was applied to the Parental Authority Questionnaire and to the Control Theory Questionnaire to validate their factors. Note that the adolescents responded to the questionnaires anonymously and online, so that data related to their schools, cities, and neighborhoods were not available. For that reason, multilevel modeling was not used. The means, standard deviations, and Pearson correlations between parenting styles and parental social control were calculated. Logistic regressions were calculated to assess how sexting was related to gender, age group, parenting styles, and parental social control. 


\section{Results}

All participants reported using instant messaging apps (100\%). With respect to social media: $70 \%(n=321,70.1 \%)$ used Snapchat and about $60 \%$ ( $n=278,60.7 \%$ ) used Facebook chat. Seventy adolescents reported using Instagram (12.8\%). Snapchat was used by $51.5 \%$ of the boys compared to $75.4 \%$ of the girls $\left(\chi^{2}(1)=21.39, p<.001, O R=2.88,95 \% \mathrm{Cl}=[1.82,4.56]\right)$. Facebook chat was used by $73.3 \%$ of the boys compared to $57.1 \%$ of the girls $\left(\chi^{2}(1)=8.58, p=.002, O R=2.04,95 \% \mathrm{Cl}=[1.27,3.33]\right)$. Instagram was used by $4.0 \%$ of the boys compared to $15.4 \%$ of the girls $\left(\chi^{2}(1)=9.19, p=.002, O R=4.42,95 \% \mathrm{Cl}=[1.56,12.50]\right)$. Grade level differences were found only regarding Instagram use, which was more frequent among middle-school (19.4\%) than among highschool students (8.8\%), $\left(\chi^{2}(1)=10.81, p=.001, O R=2.50,95 \% \mathrm{Cl}=[1.43,4.35]\right)$.

\section{Sexting}

Results pertaining to the distribution of sexting are shown in Table 1: about $29 \%$ of the participants reported sending sexual messages with or without photos, and about $20 \%$ reported sending sexual photos. That is, most sexual messages included photos (91 of 132, 69.0\%). About half of these messages were sent to a girlfriend/boyfriend, while the others were sent to peer-group friends, potential girlfriends/boyfriends, or strangers. Similarly, nude or semi-nude photos were sent mostly (52\%) to a girlfriend/boyfriend, whereas, in other cases, they were sent to friends in the peer group, a potential girlfriend/boyfriend, or strangers. The majority (69\%) did not share with others the fact that they had engaged in sexting; $25 \%$ shared this information with their friends.

About $12 \%$ of the participants admitted asking others to send them nude or semi-nude photos, addressing a girlfriend/boyfriend in most cases (45\%) and, in other cases, friends in their peer group, a potential girlfriend/boyfriend, or strangers. Finally, almost one-third (32\%) of the participants reported being asked by others to send sexual photos, with requests coming mainly from strangers (45\%), as well as from a girlfriend/boyfriend, peer-group friends, or a potential girlfriend/boyfriend. Regarding this request, $44 \%$ of participants did not tell anyone about receiving such a request, while $39 \%$ told someone else, mostly friends, siblings, a counselor, a teacher, another adult, or a parent.

Table 1. Sexting Distribution ( $N=458)$.

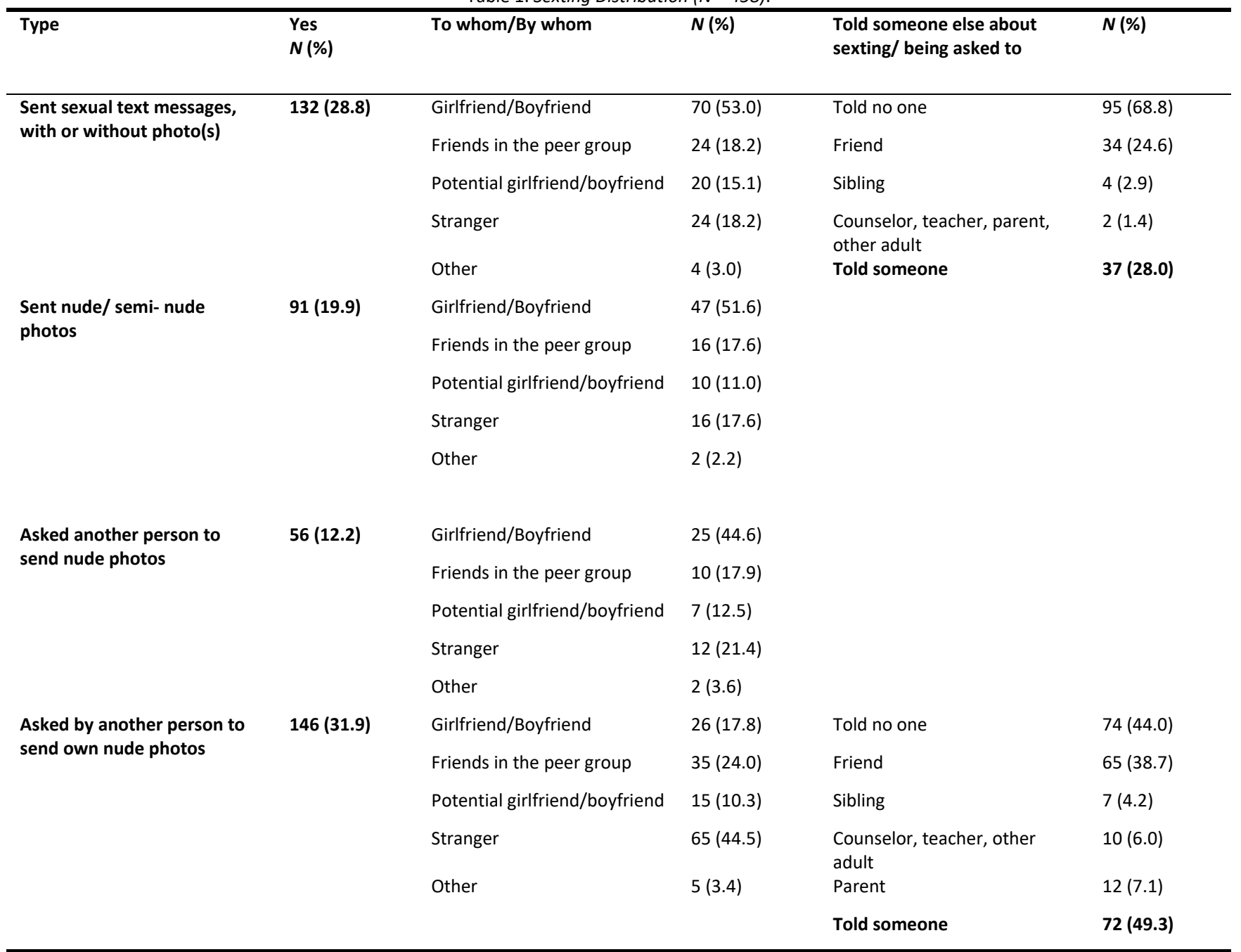


Based on the distribution, we compiled six sexting variables (categories shown in bold in Table 1 are those that appear also in Table 2) and compared them by gender and age group.

\section{Sexting by Gender and Age Group}

The results depicted in Table 2 show no gender differences in sexting (sending messages with or without photos), but indicate that sexting is more common among high-school students (age range $15-18, M=16.52, S D=0.92$ ) than among middle-school students (age range $12-15, M=14.02, S D=0.85$ ). Asking others to send nude or semi-nude photos was more common among boys than among girls, and more common among high-school students than among middle-school students. No gender differences or age group differences were found regarding being asked to send nude photos of oneself or regarding telling others about engaging in sexting.

Table 2. Distribution of Sexting by Gender and age Group ( $N=458)$.

\begin{tabular}{|c|c|c|c|c|c|c|c|c|c|}
\hline Variable & $\begin{array}{l}\text { Total } \\
N(\%)\end{array}$ & $\begin{array}{l}\text { Boys } \\
N(\%)\end{array}$ & $\begin{array}{l}\text { Girls } \\
N(\%)\end{array}$ & $\chi^{2}(1)$ & $\begin{array}{c}O R \\
(95 \% \mathrm{Cl})\end{array}$ & $\begin{array}{l}\text { Middle } \\
\text { School } \\
N(\%)\end{array}$ & $\begin{array}{l}\text { High School } \\
\qquad N(\%)\end{array}$ & $\chi^{2}(1)$ & $\begin{array}{c}\text { OR } \\
(95 \% \mathrm{Cl})\end{array}$ \\
\hline $\begin{array}{l}\text { Sent sexual messages with or } \\
\text { without photos }\end{array}$ & $\begin{array}{c}132 \\
(28.8)\end{array}$ & $\begin{array}{c}35 \\
(34.7)\end{array}$ & $\begin{array}{c}97 \\
(27.2)\end{array}$ & 2.15 & $\begin{array}{c}0.70 \\
(0.44,1.13)\end{array}$ & $\begin{array}{c}32 \\
(18.3)\end{array}$ & $\begin{array}{c}100 \\
(35.3)\end{array}$ & $15.32 * * *$ & $\begin{array}{c}2.44 \\
(1.55,3.85)\end{array}$ \\
\hline $\begin{array}{l}\text { Sent sexual message(s) including } \\
\text { photo(s) }\end{array}$ & $\begin{array}{c}91 \\
(19.9)\end{array}$ & $\begin{array}{c}24 \\
(23.8)\end{array}$ & $\begin{array}{c}67 \\
(18.8)\end{array}$ & 1.58 & $\begin{array}{c}0.71 \\
(0.41,1.21)\end{array}$ & $\begin{array}{c}17 \\
(9.7)\end{array}$ & $\begin{array}{c}74 \\
(26.1)\end{array}$ & $19.08^{* * *}$ & $\begin{array}{c}3.40 \\
(1.92,6.02)\end{array}$ \\
\hline $\begin{array}{l}\text { Asked another person to send } \\
\text { nude or semi-nude photos of } \\
\text { themselves }\end{array}$ & $\begin{array}{c}56 \\
(12.2)\end{array}$ & $\begin{array}{c}23 \\
(22.8)\end{array}$ & $\begin{array}{c}33 \\
(9.2)\end{array}$ & $13.43^{* * *}$ & $\begin{array}{c}2.89 \\
(1.61,5.21)\end{array}$ & $\begin{array}{c}12 \\
(6.9)\end{array}$ & $\begin{array}{c}44 \\
(15.5)\end{array}$ & $7.61^{* *}$ & $\begin{array}{c}0.40 \\
(0.20,0.78)\end{array}$ \\
\hline $\begin{array}{l}\text { Was asked by another person to } \\
\text { send nude or semi-nude self- } \\
\text { photo(s) }\end{array}$ & $\begin{array}{c}146 \\
(31.9)\end{array}$ & $\begin{array}{c}25 \\
(24.8)\end{array}$ & $\begin{array}{c}121 \\
(33.9)\end{array}$ & 3.03 & $\begin{array}{c}0.64 \\
(0.39,1.06)\end{array}$ & $\begin{array}{c}49 \\
(28.0)\end{array}$ & $\begin{array}{c}97 \\
(34.3)\end{array}$ & 1.96 & $\begin{array}{c}0.75 \\
(0.49,1.12)\end{array}$ \\
\hline $\begin{array}{l}\text { Told others about sending sexual } \\
\text { messages }(n=132)\end{array}$ & $\begin{array}{c}37 \\
(28.0)\end{array}$ & $\begin{array}{c}7 \\
(20.0)\end{array}$ & $\begin{array}{c}30 \\
(30.9)\end{array}$ & 1.52 & $\begin{array}{c}1.79 \\
(0.70,4.55)\end{array}$ & $\begin{array}{c}10 \\
(31.3)\end{array}$ & $\begin{array}{c}27 \\
(27.0)\end{array}$ & 0.22 & $\begin{array}{c}0.81 \\
(0.34,1.94)\end{array}$ \\
\hline $\begin{array}{l}\text { Told others that someone asked } \\
\text { them to send nude or semi-nude } \\
\text { photos }(n=146)\end{array}$ & $\begin{array}{c}72 \\
(49.3)\end{array}$ & $\begin{array}{c}11 \\
(44.0)\end{array}$ & $\begin{array}{c}61 \\
(50.4)\end{array}$ & 0.34 & $\begin{array}{c}1.29 \\
(0.54,3.08)\end{array}$ & $\begin{array}{c}28 \\
(57.1)\end{array}$ & $\begin{array}{c}44 \\
(45.4)\end{array}$ & 1.81 & $\begin{array}{c}0.62 \\
(0.31,1.24)\end{array}$ \\
\hline
\end{tabular}

Note. Middle school (age range $12-15, M=14.02, S D=0.85$ ), high school (age range $15-18, M=16.52, S D=0.92$ ).

${ }^{*} p<.05,{ }^{* *} p<.01, * * * p<.001$.

\section{Parenting Style and Parental Social Control}

As can be seen in Table 3, adolescents perceived their parents as utilizing mostly the authoritative parenting style and using permissive or authoritarian styles less. They rated parental social control somewhat above midscale. The authoritative parenting style demonstrated a positive correlation with the permissive style and with parental social control and a negative correlation with the authoritarian parenting style. The permissive parenting style was also negatively related to the authoritarian style and positively related to parental social control. Finally, parental social control was negatively related to the authoritarian parenting style.

Table 3. Means, Standard Deviations, and Correlations Among Parenting Styles and Parental Social Control ( $N=458)$.

\begin{tabular}{|c|c|c|c|c|}
\hline & $M(S D)$ & Permissive & Authoritarian & Social control \\
\hline Authoritative & $3.44(0.80)$ & $.37 * * *$ & $-.32 * * *$ & $.64 * * *$ \\
\hline Permissive & $2.61(0.59)$ & & $-.24 * * *$ & $.24 * * *$ \\
\hline Authoritarian & $2.74(0.81)$ & & & $-.34 * * *$ \\
\hline Social control & $3.44(0.64)$ & & & \\
\hline
\end{tabular}

Note. Authoritative, permissive, and authoritarian parenting styles-from the Parental Authority Questionnaire (Buri, 1991). Parental social control - from the Control Theory Questionnaire (Hirschi, 1969).

${ }^{* * *} p<.001$, range: $1-5$

Logistic regressions were used to explore how sexting was predicted by gender, age group, parenting styles, and social control (see Table 4). Sexting variables were defined dichotomously as $1=$ existent and $0=$ nonexistent. The dichotomous predictors were gender ( 1 = boys, $0=$ girls $)$ and age group $(1=$ high school, $0=$ middle school). It should be noted that none of the continuous predictors violated the normality assumptions (maximum skewness value was $0.63, S E=0.10$ ) and that the intercorrelations among the predictors ranged between $r=-.32$ and $r=.63(p<.001)$, thus not reflecting multicollinearity. 
Table 4. Logistic Regressions Predicting Sexting by Gender, age Group, Parenting Styles, and Parental Social Control.

\begin{tabular}{|c|c|c|c|c|c|c|}
\hline & \multicolumn{2}{|c|}{$\begin{array}{c}\text { Sent sexual messages with or without } \\
\text { photos }\end{array}$} & \multicolumn{2}{|c|}{$\begin{array}{l}\text { Asked another person to send nude or } \\
\text { semi-nude photos }\end{array}$} & \multicolumn{2}{|c|}{$\begin{array}{l}\text { Asked by another person to send own } \\
\text { nude or semi-nude photos }\end{array}$} \\
\hline & $B(S E)$ & OR $(95 \% \mathrm{Cl})$ & $B(S E)$ & OR $(95 \% \mathrm{Cl})$ & $B(S E)$ & OR (95\% Cl) \\
\hline Gender & $0.32(0.25)$ & $1.37(0.84,2.24)$ & $0.98 * *(0.31)$ & $2.67(1.46,4.91)$ & $-0.48(0.26)$ & $0.62(0.37,1.03)$ \\
\hline Age group & $0.89 * * *(0.24)$ & $2.44(1.53,3.89)$ & $0.96 * *(0.35)$ & $2.60(1.30,5.23)$ & $0.37(0.22)$ & $1.45(0.95,2.23)$ \\
\hline Authoritative & $0.10(0.18)$ & $1.10(0.78,1.57)$ & $-0.09(0.24)$ & $0.91(0.57,1.47)$ & $0.22(0.18)$ & $1.25(0.88,1.76)$ \\
\hline Permissive & $0.02(0.20)$ & $1.02(0.69,1.51)$ & $0.63 *(0.27)$ & $1.87(1.09,3.20)$ & $0.01(0.19)$ & $1.01(0.69,1.46)$ \\
\hline Authoritarian & $-0.06(0.14)$ & $0.94(0.71,1.24)$ & $-0.09(0.19)$ & $0.92(0.63,1.34)$ & $0.16(0.14)$ & $1.17(0.89,1.53)$ \\
\hline Social control & $-0.57 *(0.22)$ & $0.57(0.37,0.88)$ & $-0.63 *(0.30)$ & $0.53(0.29,0.97)$ & $-0.74 * * *(0.22)$ & $0.48(0.31,0.73)$ \\
\hline$\chi^{2}(6)$ & \multicolumn{2}{|c|}{$25.80 * * *$} & \multicolumn{2}{|c|}{$29.97 * * *$} & \multicolumn{2}{|c|}{$23.25^{* *}$} \\
\hline Nagelkerke's $R^{2}$ & \multicolumn{2}{|c|}{$.08^{* * *}$} & \multicolumn{2}{|c|}{$.12^{* * *}$} & \multicolumn{2}{|c|}{$.07 * *$} \\
\hline
\end{tabular}

As shown in Table 4, the three models are significant, yet the explained variance is low. Sending sexually explicit messages with or without photos was positively predicted by age group, as illustrated in Table 2, and negatively predicted by parental social control. Lower social control was related to an increased likelihood of sending sexual messages with or without photos.

Asking another person to send nude or semi-nude photos was positively predicted by gender (male) and age group, as indicated in Table 2. In addition, it was positively predicted by permissive parenting style and negatively predicted by parental social control. A perception of highly permissive parenting style and of low parental social control was related to increased likelihood of asking another person to send photos.

Being asked by another person to send nude or semi-nude photos of oneself was negatively predicted by parental social control, suggesting that lower parental social control is related to an increased likelihood of this type of sexting.

Neither the regression model for telling others about sending sexual messages $\left(\chi^{2}(6)=4.86, p=.561, n=132\right)$ nor the regression model for telling others about being asked to send sexual messages $\left(\chi^{2}(6)=3.34, p=.765, n=146\right)$ was significant.

\section{Discussion}

The present study examined sexting among adolescents and its relationship to gender, perceived parenting style, and parental social control as evidenced through adolescents' self-reported social bonds.

The study's findings show that sexting is prevalent in the age group under examination among both boys and girls, with $30 \%$ of the participants reporting that they sent sexual messages or messages containing nude or semi-nude photos. Moreover, sexting is more common among high-school students than among middle-school students. This finding is supported by other recent studies, which found the prevalence of sexting to be as high as 32\%, with greater prevalence in the older (18-year-olds) than in the younger (12-year-olds) age group (Cooper et al., 2016; Dake et al., 2012; Mitchell et al., 2012; Rice et al., 2012). In a study of 480 adolescents, one-fifth of the participants reported being involved in sexting against their will (Drouin et al., 2015), whereas in the present study, one-third of the participants reported that others asked them to send nude photos of themselves, with $45 \%$ of these requests coming from strangers. These prevalence rates suggest that sexting is becoming another sign of adolescents' sexual development in the modern age. At the same time, this finding of prevalence is very important in view of the correlation found between more time spent online and sexual harassment, sexual exploitation, and receiving inappropriate requests in the online space (Baumgartner et al., 2010; Jonsson et al., 2014). In Israel, daily screen time among adolescents is relatively higher than that that reported in other European countries (Boniel-Nissim, Lenzi, et al., 2015).

More than half of the study participants reported telling no one about being asked to send sexual messages or photos, and only a small number chose to tell an adult. This may be explained by the current finding of a relationship between lower parental social control, which suggests the lack of parental guidance or direction, and an increased likelihood of sending sexual messages with or without photos. It bears emphasizing that for the most part, participants' parents were unaware of the extent and seriousness of their children's exposure (D'Antona et al., 2010). In fact, a widescale study in Europe found that only $21 \%$ of parents whose children were exposed to sexting were aware of the exposure, $52 \%$ of parents thought their children had no exposure to sexting, and $27 \%$ 
responded not knowing (Livingstone \& Gorzig, 2012). The low percentage of adolescents who tell their parents about sexting is typical of adolescence, a time when teenagers distance themselves from their parents and move closer to their peer group (Steinberg, 2008). This percentage is also consistent with the low percentage of online victims who tell others (Heirman \& Walrave, 2008). In this context, it is important to note that although Israeli parents - unlike parents in other Western countries-are characterized as "child-oriented" (Lavee \& Katz, 2003); nevertheless, the reporting rates are low. These findings are cause for concern, because parental communication and support have been found to be an important variable in moderating the negative impact of Internet use (Boniel-Nissim, Tabak, et al., 2015).

In the present study, asking another person to engage in visual sexting (with nude or semi-nude photos) was found to be more prevalent among boys than among girls. This finding is in line with other studies, which indicate that members of both genders believed that boys were more likely than girls to make such requests (Symons et al., 2018). Indeed, it was found that $47 \%$ of adolescents felt pressure from males to engage in sexting (National Campaign to Prevent Teen Pregnancy, 2008). The higher tendency of boys to engage in sexting may be because of the social pressure to express their masculinity (Ogletree et al., 2014). For their part, girls have reported their concerns about risking their moral reputation if they were to be caught sexting (Spencer et al., 2015). Another possible explanation may be the fact that most of the video clips that warn of the risks of sexting feature girlsrather than boys - sending revealing images of themselves. Therefore, boys may not identify with the warnings or may feel they are not the ones being targeted.

Studies that examined gender differences in sexting and its use as a legitimate means of communication (Davidson, 2015) can also shed light on the current findings. In the earlier studies, girls perceived sexting as prevalent among adolescents, while recognizing that its use differed among individuals. Sexting was experienced as either despicable or normal, depending on the context and use. Three motives for sexting were reported: to express affection in a romantic relationship, for sex purposes, and to strengthen friendships. Girls experienced sexting as a statement of power and popularity. Both girls and boys perceived sexting as characteristic of stages in an intimate relationship and thus as part of affectionate communication. It stands to reason that sexting is a behavior that is influenced by the media. Both genders reported that boys received "masculinity points" for sending their own nude photos or for distributing a girlfriend's pictures. In contrast, both boys and girls perceived girls who sent their own nude photos as "cheap" and lacking in self-esteem (Ringrose et al., 2013).

The present study investigated the prevalence of sexting and its relationship to other factors based on data obtained using selfreport methods. Notwithstanding, it is important to acknowledge the findings regarding parental social control, which indicate that an absence of supervision is related to the increased likelihood of sending nude photos. In addition, a reported permissive parenting style was correlated with the likelihood of asking someone else to send nude or semi-nude photos. Both of these findings are supported by those of other studies. For example, Temple et al. (2014) found a correlation between sexting and the absence of parental social control. Parental restrictions on the number of messages sent per day have the potential to significantly reduce the risk of adolescents sending messages containing either nude or semi-nude photos (Lenhart, 2009). However, even when restrictions are imposed, one-quarter of adolescents appear to find ways to bypass them (Cox Communications, 2009). Overall, parenting behaviors and the parent-adolescent relationships may offer important insights into the processes that influence adolescent sexting. Parenting constructs, such as warmth, psychological control, communication, and monitoring (in the authoritative parenting style) have been found to be influential in the development of adolescents' safe sexual behavior (Norman, 2017). It is important to note that a previous study found a correlation between sexual interaction online and online victimization (Kerstens \& Stol, 2014). Moreover, it seems that even data conveyed through consensual sexting might be utilized at a later point in time for revenge pornography (i.e., the unauthorized public distribution of another person's nude pictures with the intent to humiliate) or for sextortion (threatening to expose nude, or embarrassing sexual images without consent, usually for the purpose of procuring additional images, sexual acts, money, etc.) (Patchin \& Hinduja, 2020; Wolak et al., 2018). It has been found that the detrimental impact that such behaviors have on the victims' mental health is similar to symptoms that present among sexual assault survivors, including anxiety and panic attacks, humiliation, and shame (Walker \& Sleath, 2017). Engaging in sexting also may be considered a form of child pornography with all its legal implications (Walker \& Sleath, 2017); hence, sexting among adolescents, even with consent, involves a potential risk.

The present study focused on examining the sexting behaviors among teenage girls and boys in relation to several factors. The importance of this study lies in the suggestion that sexting may be a modern age phenomenon that is yet another manifestation of adolescent sexual interest and development. In the presence of suitable control, sexting may be deemed a socially appropriate behavior that allows adolescents to express their budding sexuality. Nevertheless, sexting may put young adolescents at risk, due to violations of privacy, thus leading to negative consequences. Hence, sexting needs to be mediated by nonjudgmental communication, which underscores the importance of active parental involvement and direct communication, or communication through the mediation of school counselors. The perception of this behavior as a social phenomenon rather than as a pornographic pastime might help educate young people to think about how to communicate appropriately and how to regulate their activities, pleasures, and emotions, while remaining alert to the potential dangers of online media. Currently, educational campaigns that address the risks of sexting use scare tactics, stressing the risks of bullying, criminal prosecution, female victimization, and blame (Döring, 2014). In this day and age, however, this may not be the educational approach needed, and we should consider changing the terminology from "risky" to "healthy" (Döring, 2014). School counselors involved in sex education within the school curriculum 
must learn to understand that adolescents' learning space includes various media interactions with friends, parents, and educators, as well as with more distanced circles, the latter involving people who--at best-the students know of indirectly, or--at worst-others who are complete strangers. All of these contacts play a role in the knowledge adolescents acquire about sexuality and relationships (Davidson, 2015), whether they interact with them at school, at home, at parties, at the mall, in physical and online encounters with friends, or wherever they may be.

The results of the present study reinforce the need for further studies to examine the ways in which the significant adults in the lives of adolescents (such as parents, educators, and school counselors) perceive sexting, whether they acknowledge its existence, and how they cope with it. Are there gaps in perceptions, and if so, can they be bridged? What are the parental and educational implications of these perceptions? Providing answers to these questions, among others, will be helpful in establishing educational counseling programs, parent education programs, and interventions, intended to view these online experiments as an expression of adolescents' normative sexual development, while safeguarding their own privacy and that of others.

\section{Limitations and Further Research}

The findings of this study should be considered in light of several limitations. First, the research population was homogeneous, comprising only Israeli adolescents. Due to possible expected cultural differences, future studies should examine other age groups and diverse religious and cultural populations, to ascertain the replicability and generalizability of the findings. As the study was based on a convenience sample gathered online, its findings can only represent those who were already online and willing to respond to questions about sexting behaviors. Furthermore, as this was not a representative sample, the ratio of boys to girls could not be controlled. Future studies should strive to use a more representative sample. Further research might consider different conceptualizations of parenting styles, rather than merely the classic one (by including a fourth style, e.g., that of uninvolved parenting, or by addressing other parenting factors). Likewise, parenting style could be studied in relation to family contexts that include co-parenting, divorced parents, or single parents.

Recruiting participants via the Internet raises several questions, with which the research in this field must contend. The advantage of using a sample recruited online is that this data collection method is quick, direct, inherently indicates the responders' willingness to participate, and it may encourage a degree of openness and honesty among participants which is difficult to come by using alternative data collection methods. In the context of sexting research, the ability to maintain anonymity, as well as the absence of any background information, probably facilitates the data collection process. At the same time, this recruitment method may imply also a certain bias, as it attracts participants who are already drawn to the topic under investigation. Hence, although the method has advantages and disadvantages, it does provide direct access to the target population; however, it is contextually appropriate, given that the sexting behavior makes use of digital communication.

The current study limited its exploration of the social control theory to the aspect of parental social control, by examining only the social bonds that can reflect parental influence. However, given the results of the study, it is important to address the other bonds (friends, and teachers) that may affect adolescents' social control.

The regression models did not provide a strong explanation of the variance. Consequently, it is recommended that future studies attempt to address the ways in which Internet dependence and sexting among adolescents are related to adolescents' psychological variables, such as attachment, relationships with peers, and additional behaviors related to online sexual activities.

Despite these lacunae, we view the current study as taking an important step in understanding sexting and its correlation with parental presence.

\section{References}

Agustina, J. R. (2015). Understanding cyber victimization: Digital architectures and the disinhibition effect. International Journal of Cyber Criminology, 9(1), 35-54. http://dx.doi.org/10.5281/zenodo.22239

Anderson, M. (2015). Technology device ownership: 2015. Pew Research Center: Internet \& Technology.

http://www.pewinternet.org/2015/10/29/technology-device-ownership-2015

Arcabascio, C. (2010). Sexting and teenagers: Omg ru going 2 jail??? Richmond Journal of Law \& Technology, 16(3), Article 4. https://scholarship.richmond.edu/jolt/vol16/iss3/4

Baumgartner, S. E., Sumter, S. R., Peter, J., Valkenburg, P. M., \& Livingstone, S. (2014). Does country context matter? Investigating the predictors of teen sexting across Europe. Computers in Human Behavior, 34, 157-164.

https://doi.org/10.1016/j.chb.2014.01.041 
Baumgartner, S. E., Valkenburg, P. M., \& Peter, J. (2010). Unwanted online sexual solicitation and risky sexual online behavior across the lifespan. Journal of Applied Developmental Psychology, 31(6), 439-447. https://doi.org/10.1016/j.appdev.2010.07.005

Baumrind, D. (1977). What research is teaching us about the differences between authoritative and authoritarian child-rearing styles. In D. E. Hamachek (Ed.), Human dynamics in psychology and education: Selected readings (3rd ed., pp. 213-220). Allyn \& Bacon.

Baumrind, D. (1991). The influence of parenting style on adolescent competence and substance use. The Journal of Early Adolescence, 11(1), 56-95. https://doi.org/10.1177/0272431691111004

Boehnke, M. (2011). Gender role attitudes around the globe: Egalitarian vs. traditional views. Asian Journal of Social Science, 39(1), 57-74. https://www.jstor.org/stable/43500538

Boniel-Nissim, M., Efrati, Y., \& Dolev-Cohen, M. (2020). Parental mediation regarding children's pornography exposure: The role of parenting style, protection motivation and gender. The Journal of Sex Research, 57(1), 42-51.

http://doi.org/10.1080/00224499.2019.1590795

Boniel-Nissim, M., Lenzi, M., Zsizos, E., Gaspar de Matos, M., Gommans, R., Harel-Fisch, Y., Djalovski, A., \& van der Sluijs, W. (2015). International trends in electronic media communication (EMC) among 11- to 15-year-olds in 30 countries from 2002 to 2010: Association with ease of communication with friends of the opposite sex. European Journal on Public Health, 25(Suppl. 2), 41-45. https://doi.org/10.1093/eurpub/ckv025

Boniel-Nissim, M., Tabak, I., Mazur, J., Borraccino, A., Brooks, F., Gommans, R., van der Sluijs, W., Zsiros, E., Craig, W., HarelFisch, Y., \& Finne, E. (2015). Supportive communication with parents moderates the negative effects of electronic media use on life satisfaction during adolescence. International Journal of Public Health, 60(2), 189-198. https://doi.org/10.1007/s00038-0140636-9

Buri, J. R. (1991). Parental Authority Questionnaire. Journal of Personality Assessment, 57(1), 110-119.

https://doi.org/10.1207/s15327752jpa5701_13

Casas, J. A., Ojeda, M., Elipe, P., \& Del Rey, R. (2019). Exploring which factors contribute to teens' participation in sexting. Computers in Human Behavior, 100, 60-69. https://doi.org/10.1016/j.chb.2019.06.010

Cooper, K., Quayle, E., Jonsson, L., \& Svedin, C. G. (2016). Adolescents and self-taken sexual images: A review of the literature. Computers in Human Behavior, 55(Part B), 706-716. https://doi.org/10.1016/j.chb.2015.10.003

Cox Communications (2009). Teen Online \& Wireless Safety Survey: Cyberbullying, sexting, and parental controls. http://www.scribd.com/doc/20023365/2009-Cox-Teen-Online-Wireless-Safety-Survey-Cyberbullying-Sexting-and-ParentalControls

Dake, J. A., Price, J. H., Maziarz, L., \& Ward, B. (2012). Prevalence and correlates of sexting behavior in adolescents. American Journal of Sexuality Education, 7(1), 1-15. https://doi.org/10.1080/15546128.2012.650959

Daneback, K., Træen, B., \& Månsson, S.-A. (2009). Use of pornography in a random sample of Norwegian heterosexual couples. Archives of Sexual Behavior, 38(5), 746-753. https://doi.org/10.1007/s10508-008-9314-4

D'Antona, R., Kevorkian, M., \& Russom, A. (2010). Sexting, texting, cyberbullying and keeping youth safe online. Journal of Social Sciences,6(4), 523-528. https://doi.org/10.3844/jssp.2010.523.528

Darling, N., \& Steinberg, L. (1993). Parenting style as context: An integrative model. Psychological Bulletin, 1113(3), $487-496$. https://doi.org/10.1037/0033-2909.113.3.487

Davidson, J. (2015). Sexting: Gender and teens. Springer.

De Gaston, J. F., Weed, S., \& Jensen, L. (1996). Understanding gender differences in adolescent sexuality. Adolescence, 31(121), 217-231.

de Graaf, H., Vanwesenbeeck, I., Woertman, L., \& Meeus, W. (2011). Parenting and adolescents' sexual development in western societies. European Psychologist, 16(1), 21-31. https://doi.org/10.1027/1016-9040/a000031 
Delevi, R., \& Weisskirch, R. S. (2013). Personality factors as predictors of sexting. Computers in Human Behavior, 29(6), 25892594. https://doi.org/10.1016/j.chb.2013.06.003

Dir, A. L., Coskunpinar, A., Steiner, J. L., \& Cyders, M. A. (2013). Understanding differences in sexting behaviors across gender, relationship status, and sexual identity, and the role of expectancies in sexting. Cyberpsychology, Behavior, and Social Networking, 16(8), 568-574. http://doi.org/10.1089/cyber.2012.0545

Döring, N. (2014). Consensual sexting among adolescents: Risk prevention through abstinence education or safer sexting? Cyberpsychology: Journal of Psychosocial Research on Cyberspace, 8(1), Article 9. http://dx.doi.org/10.5817/CP2014-1-9

Drouin, M., Ross, J., \& Tobin, E. (2015). Sexting: A new, digital vehicle for intimate partner aggression? Computers in Human Behavior, 50, 197-204. https://doi.org/10.1016/j.chb.2015.04.001

Drouin, M., Vogel, K. N., Surbey, A., \& Stills, J. R. (2013). Let's talk about sexting, baby: Computer-mediated sexual behaviors among young adults. Computers in Human Behavior, 29(5), A25-A30. https://doi.org/10.1016/j.chb.2012.12.030

Duggan, M., Ellison, N. B., Lampe, C., Lenhart, A., \& Madden, M. (2015). Social Media Update 2014. Pew Research Center. http://www.pewinternet.org/2015/01/09/social-media-update-2014/

Englander, E. (2012). Low risk associated with most teenage sexting: A study of 617 18-year-olds. MARC Research Reports. https://vc.bridgew.edu/marc_reports/6

Fagan, J., \& Pabon, E. (1990). Contributions of delinquency and substance use to school dropout among inner-city youths. Youth \& Society, 21(3), 306-354. https://doi.org/10.1177/0044118X90021003003

Garcia, J. R., Gesselman, A. N., Siliman, S. A., Perry, B. L., Coe, K., \& Fisher, H. E. (2016). Sexting among singles in the USA: Prevalence of sending, receiving, and sharing sexual messages and images. Sexual Health, 13(5), 428-435.

https://doi.org/10.1071/SH15240

Gordon-Messer, D., Bauermeister, J. A., Grodzinski, A., \& Zimmerman, M. (2013). Sexting among young adults. Journal of Adolescent Health, 52(3), 301-306. https://doi.org/10.1016/j.jadohealth.2012.05.013

Gottfredson, M. R., \& Hirschi, T. (1990). A general theory of crime. Stanford University Press.

Hasinoff, A. A., \& Shepherd, T. (2014). Sexting in context: Privacy norms and expectations. International Journal of Communication, 8, 2932-2955. https://ijoc.org/index.php/ijoc/article/view/2264

Heirman, W., \& Walrave, M. (2008). Assessing concerns and issues about the mediation of technology in cyberbullying. Cyberpsychology: Journal of Psychosocial Research on Cyberspace, 2(2), Article 1.

https://cyberpsychology.eu/article/view/4214/3256

Henderson, L., \& Morgan, E. (2011). Sexting and sexual relationships among teens and young adults. McNair Scholars Research Journal, 7(1), Article 9. https://scholarworks.boisestate.edu/mcnair_journal/vol7/iss1/9

Hirschi, T. (1969). Causes of delinquency. University of California Press.

Houck, C. D., Barker, D., Rizzo, C., Hancock, E., Norton, A., \& Brown, L. K. (2014). Sexting and sexual behavior in at-risk adolescents. Pediatrics, 133(2), e276-e282. https://doi.org/10.1542/peds.2013-1157

Hudson, H. K., \& Fetro, J. V. (2015). Sextual activity: Predictors of sexting behaviors and intentions to sext among selected undergraduate students. Computers in Human Behavior, 49, 615-622. https://doi.org/10.1016/j.chb.2015.03.048

Jacobson, K. C., \& Crockett, L. J. (2000). Parental monitoring and adolescent adjustment: An ecological perspective. Journal of Research on Adolescence, 10(1), 65-97. https://psycnet.apa.org/record/2000-13351-004

Jonsson, L. S., Priebe, G., Bladh, M., \& Svedin, C. G. (2014). Voluntary sexual exposure online among Swedish youth - social background, Internet behavior and psychosocial health. Computers in Human Behavior, 30, 181-190.

https://doi.org/10.1016/j.chb.2013.08.005 
Kerstens, J., \& Stol, W. (2014). Receiving online sexual requests and producing online sexual images: The multifaceted and dialogic nature of adolescents' online sexual interactions. Cyberpsychology: Journal of Psychosocial Research on Cyberspace, 8(1), Article 8. https://doi.org/10.5817/CP2014-1-8

Kiefer, A. K., \& Sanchez, D. T. (2007). Scripting sexual passivity: A gender role perspective. Personal Relationships, 14(2), 269290. https://doi.org/10.1111/j.1475-6811.2007.00154.x

Klettke, B., Hallford, D. J., \& Mellor, D. J. (2014). Sexting prevalence and correlates: A systematic literature review. Clinical psychology review, 34(1), 44-53.

Klettke, B., Hallford, D. J., Clancy, E., Mellor, D. J., \& Toumbourou, J. W. (2019). Sexting and psychological distress: The role of unwanted and coerced sexts. Cyberpsychology, Behavior, and Social Networking, 22(4), 237-242.

https://doi.org/10.1089/cyber.2018.0291

Klettke, B., Mellor, D., Silva-Myles, L., Clancy, E., \& Sharma, M. (2018). Sexting and mental health: A study of Indian and Australian young adults. Cyberpsychology: Journal of Psychosocial Research on Cyberspace, 12(2), Article 2.

https://doi.org/10.5817/CP2018-2-2

Kopecký, K. (2012). Sexting among Czech preadolescents and adolescents. The New Educational Review, 28(2), 39-48.

Kosenko, K., Luurs, G., \& Binder, A. R. (2017). Sexting and sexual behavior, 2011-2015: A critical review and meta-analysis of a growing literature. Journal of Computer-Mediated Communication, 22(3), 141-160. https://doi.org/10.1111/jcc4.12187

Lapidot-Lefler, N., \& Barak, A. (2012). Effects of anonymity, invisibility, and lack of eye-contact on toxic online disinhibition. Computers in Human Behavior, 28(2), 434-443. https://doi.org/10.1016/j.chb.2011.10.014

Lavee, Y., \& Katz, R. (2003). The family in Israel: Between tradition and modernity. Marriage \& Family Review, 35(1-2), $193-217$. https://doi.org/10.1300/J002v35n01_11

Lenhart, A. (2009). Teens and sexting: How and why minor teens are sending sexually suggestive nude or nearly nude images via text messaging. Pew Research Center: Internet \& Technology. https://www.pewresearch.org/internet/2009/12/15/teens-andsexting/

Lenhart, A., Ling, R., Campbell, S., \& Purcell, K. (2010). Teens and mobile phones: Text messaging explodes as teens embrace it as the centerpiece of their communication strategies with friends. Pew Research Center: Internet \& Technology.

https://www.pewresearch.org/internet/2010/04/20/teens-and-mobile-phones/

Lewis, M. A., \& Butterfield, R. M. (2005). Antecedents and reactions to health-related social control. Personality and Social Psychology Bulletin, 31(3), 416-427. https://doi.org/10.1177/0146167204271600

Lewis, M. A., Butterfield, R. M., Darbes, L. A., \& Johnston-Brooks, C. (2004). The conceptualization and assessment of healthrelated social control. Journal of Social and Personal Relationships, 21(5), 669-687. https://doi.org/10.1177/0265407504045893

Liska, A. E., \& Reed, M. D. (1985). Ties to conventional institutions and delinquency: Estimating reciprocal effects. American Sociological Review, 50(4), 547-560. https://doi.org/10.2307/2095438

Livingstone, S. M., Haddon, L., \& Görzig, A. (2012). Children, risk and safety on the Internet: Research and policy challenges in comparative perspective. Policy Press.

Maccoby, E. E., \& Martin, J. A. (1983). Socialization in the context of the family: Parent-child interaction. In P. H. Mussen \& E. M. Hetherington (Eds.), Handbook of child psychology: Socialization, personality, and social development (Vol. 4, pp. 1-101). Wiley.

Macmull, M. S., \& Ashkenazi, S. (2019). Math anxiety: The relationship between parenting style and math self-efficacy. Frontiers in Psychology, 10, Article 1721. https://doi.org/10.3389/fpsyg.2019.01721

Madigan, S., Ly, A., Rash, C. L., Van Ouytsel, J., \& Temple, J. R. (2018). Prevalence of multiple forms of sexting behavior among youth: A systematic review and meta-analysis. JAMA Pediatrics, 172(4), 327-335.

https://doi.org/10.1001/jamapediatrics.2017.5314 
Matsueda, R. L. (1982). Testing control theory and differential association: A causal modeling approach. American Sociological Review, 47(4), 489-504. https://doi.org/10.2307/2095194

McKinney, C., Donnelly, R., \& Renk, K. (2008). Perceived parenting, positive and negative perceptions of parents, and late adolescent emotional adjustment. Child and Adolescent Mental Health, 13(2), 66-73.

Mitchell, K. J., Finkelhor, D., Jones, L. M., \& Wolak, J. (2012). Prevalence and characteristics of youth sexting: A national study. Pediatrics, 129(1), 13-20. https://doi.org/10.1542/peds.2011-1730

National Campaign to Prevent Teen and Unplanned Pregnancy. (2008). The national campaign to prevent teen and unplanned pregnancy and cosmogirl.com reveal results of sex \& tech survey: Large percentage of teens posting/sending nude/semi nude images. https://powertodecide.org/what-we-do/information/resource-library/sex-and-tech-results-survey-teens-and-youngadults

Norman, J. M. (2017). Implications of parenting behaviour and adolescent attachment for understanding adolescent sexting [Doctoral dissertation, University of Windsor]. Electronic Theses and Dissertations. https://scholar.uwindsor.ca/etd/7285

Ogletree, S. M., Fancher, J., \& Gill, S. (2014). Gender and texting: Masculinity, femininity, and gender role ideology. Computers in Human Behavior, 37, 49-55. https://doi.org/10.1016/j.chb.2014.04.021

Omer, H. (1999). Parental presence: Reclaiming a leadership role in bringing up our children. Zeig Tucker \& Theisen Publishers.

Patchin, J. W., \& Hinduja, S. (2020). Sextortion among adolescents: Results from a national survey of U.S. youth. Sexual Abuse, 32(1), 30-54. https://doi.org/10.1177/1079063218800469

Pugliese, J. A., \& Okun, M. A. (2014). Social control and strenuous exercise among late adolescent college students: Parents versus peers as influence agents. Journal of Adolescence, 37(5), 543-554. https://doi.org/10.1016/j.adolescence.2014.04.008

Querido, J. G., Warner, T. D., \& Eyberg, S. M. (2002). Parenting styles and child behavior in African American families of preschool children. Journal of Clinical Child \& Adolescent Psychology, 31(2), 272-277. https://doi.org/10.1207/S15374424JCCP3102_12

Rea, J. G., \& Rossman, B. B. R. (2005). Children exposed to interparental violence: Does parenting contribute to functioning over time? Journal of Emotional Abuse, 5(1), 1-28. https://doi.org/10.1300/J135v05n01_01

Reitman, D., Rhode, P. C., Hupp, S. D. A., \& Altobello, C. (2002). Development and validation of the Parental Authority Questionnaire - Revised. Journal of Psychopathology and Behavioral Assessment, 24(2), 119-127.

https://doi.org/10.1023/A:1015344909518

Reyns, B. W., Henson, B., \& Fisher, B. S. (2014). Digital deviance: Low self-control and opportunity as explanations of sexting among college students. Sociological Spectrum, 34(3), 273-292. https://doi.org/10.1080/02732173.2014.895642

Rice, E., Gibbs, J., Winetrobe, H., Rhoades, H., Plant, A., Montoya, J., \& Kordic, T. (2014). Sexting and sexual behavior among middle school students. Pediatrics, 134(1), e21-e28. https://doi.org/10.1542/peds.2013-2991

Rice, E., Rhoades, H., Winetrobe, H., Sanchez, M., Montoya, J., Plant, A., \& Kordic, T. (2012). Sexually explicit cell phone messaging associated with sexual risk among adolescents. Pediatrics, 130(4), 667-673. https://doi.org/10.1542/peds.2012-0021

Ringrose, J., Harvey, L., Gill, R., \& Livingstone, S. (2013). Teen girls, sexual double standards and 'sexting': Gendered value in digital image exchange. Feminist Theory, 14(3), 305-323. https://doi.org/10.1177/1464700113499853

Robinson, C. C., Mandleco, B., Frost Olsen, S., \& Hart, C. H. (1995). Authoritative, authoritarian, and permissive parenting practices: Development of a new measure. Psychological Reports, 77(3), 819-830. https://doi.org/10.2466/pr0.1995.77.3.819

Rossman, B. B. R., \& Rea, J. G. (2005). The relation of parenting styles and inconsistencies to adaptive functioning for children in conflictual and violent families. Journal of Family Violence, 20(5), 261-277. https://doi.org/10.1007/s10896-005-6603-8

Scott-Little, M. C., \& Holloway, S. D. (1994). Caregivers' attributions about children's misbehavior in child-care centers. Journal of Applied Developmental Psychology, 15(2), 241-253. https://doi.org/10.1016/0193-3973(94)90015-9 
Solberg, S. (2007). Psychology of the child and the adolescent: An introduction to developmental psychology. Sifrei Hemed.

Spencer, J., Olson, J., Schrager, S., Tanaka, D., \& Belzer, M. (2015). 40. Sexting and adolescents: A descriptive study of sexting and youth in an urban population. Journal of Adolescent Health, 56(2, Suppl. 1), S22.

https://doi.org/10.1016/j.jadohealth.2014.10.044

Steinberg, L. (2008). Adolescence. McGraw-Hill.

Strassberg, D. S., Cann, D., \& Velarde, V. (2017). Sexting by high school students. Archives of Sexual Behavior, 46(6), $1667-1672$. https://doi.org/10.1007/s10508-016-0926-9

Suler, J. (2004). The online disinhibition effect. CyberPsychology \& Behavior, 7(3), 321-326.

https://doi.org/10.1089/1094931041291295

Symons, K., Ponnet, K., Walrave, M., \& Heirman, W. (2018). Sexting scripts in adolescent relationships: Is sexting becoming the norm? New Media \& Society, 20(10), 3836-3857. https://doi.org/10.1177/1461444818761869

Temple, J. R., Donna Le, V., van den Berg, P., Ling, Y., Paul, J. A., \& Temple, B. W. (2014). Brief report: Teen sexting and psychosocial health. Journal of Adolescence, 37(1), 33-36. https://doi.org/10.1016/j.adolescence.2013.10.008

Unnever, J. D., Cullen, F. T., \& Pratt, T. C. (2003). Parental management, ADHD, and delinquent involvement: Reassessing Gottfredson and Hirschi's general theory. Justice Quarterly, 20(3), 471-500. https://doi.org/10.1080/07418820300095591

Valkenburg, P. M., \& Peter, J. (2009). Social consequences of the Internet for adolescents: A decade of research. Current Directions in Psychological Science, 18(1), 1-5. https://doi.org/10.1111/j.1467-8721.2009.01595.x

Van Ouytsel, J., Torres, E., Jeong Choi, H., Ponnet, K., Walrave, M., \& Temple, J. R. (2017). The associations between substance use, sexual behaviors, bullying, deviant behaviors, health, and cyber dating abuse perpetration. The Journal of School Nursing, 33(2), 116-122. https://doi.org/10.1177/1059840516683229

Van Ouytsel, J., Van Gool, E., Walrave, M., Ponnet, K., \& Peeters, E. (2017). Sexting: Adolescents' perceptions of the applications used for, motives for, and consequences of sexting. Journal of Youth Studies, 20(4), 446-470. http://hdl.handle.net/1854/LU8203349

Van Ouytsel, J., Walrave, M., Lu, Y., Temple, J. R., \& Ponnet, K. (2018). The Associations between substance use, sexual behavior, deviant behaviors and adolescents' engagement in sexting: Does relationship context matter? Journal of Youth and Adolescence, 47(11), 2353-2370. https://doi.org/10.1007/s10964-018-0903-9

Vanwesenbeeck, I., Ponnet, K., Walrave, M., \& Van Ouytsel, J. (2018). Parents' role in adolescents' sexting behaviour. In M. Walrave, J. Van Ouytsel, K. Ponnet, \& J. Temple (Eds.), Sexting (pp. 63-80). Palgrave Macmillan.

Walker, K., \& Sleath, E. (2017). A systematic review of the current knowledge regarding revenge pornography and nonconsensual sharing of sexually explicit media. Aggression and Violent Behavior, 36, 9-24.

https://doi.org/10.1016/j.avb.2017.06.010

West, J. H., Lister, C. E., Hall, P. C., Crookston, B. T., Snow, P. R., Zvietcovich, M. E., \& West, R. P. (2014). Sexting among Peruvian adolescents. BMC Public Health, 14(1), Article 811. https://doi.org/10.1186/1471-2458-14-811

Wilchek-Aviad, Y. (2005). Model for predicting learning perseverance among boarding school students in Israel. International Journal on Disability and Human Development, 4(2), 121-130. https://doi.org/10.1515/IJDHD.2005.4.2.121

Wolak, J., Finkelhor, D., Walsh, W., \& Treitman, L. (2018). Sextortion of minors: Characteristics and dynamics. Journal of Adolescent Health, 62(1), 72-79. https://doi.org/10.1016/j.jadohealth.2017.08.014

Yaffe, Y. (2018). Convergent validity and reliability of the Hebrew version of the Parenting Styles and Dimensions Questionnaire (PSDQ) in Hebrew-speaking Israeli-Arab families. Interpersona: An International Journal on Personal Relationships, 12(2), 133144. https://doi.org/10.5964/ijpr.v12i2.303 


\section{Correspondence to:}

Michal Dolev-Cohen

Educational counseling program

Oranim Academic College of Education

Tivon

Israel

Email: michal(at)netvision.net.il

Editorial record: First submission received on March 27, 2019. Revisions received on November 27, 2019 and January $23,2020$. Accepted for publication on February 13, 2020.

Editor in charge: Lenka Dedkova

\section{About Authors}

Michal Dolev-Cohen, PhD, is a senior lecturer and researcher in cyberpsychology. She is also head of the center for learning and research online vulnerability, in the educational counseling program at Oranim Academic College of Education, Israel. Her major research interests include expression of online sexuality among adolescents (such as: sexting, sextortion, revenge porn), cyberbullying, parents-adolescents relationship in the digital era and more.

Tsameret Ricon, PhD, is a senior lecturer and head of Educational Counseling Program in the Faculty of Graduate Studies at Oranim Academic College of Education in Israel. Her research interests are in parenting, stress, school psychology, parents-educational team relationships, school counselors burnout and compassion fatigue. 